\title{
Lost in Translation: The Implementation of Community Service in Lebanese High-schools Following Decree No.8924
}

\author{
Maha Mouchantaf \\ Notre Dame University, Louaize, Beirut, Lebanon
}

\begin{abstract}
In 2012, the Lebanese Ministry of Education and Higher Education (MEHE) issued Decree No. 8924. Entitled "Project Community Service in Public and Private Secondary Schools", the decree states that all schools should apply a mandatory 60-hour community service program across the three secondary school years. There have been scattered efforts to study how the Decree is being implemented across Lebanon, with no exhaustive and thorough study yet documented. This research sought to fill part of that gap by examining the experience of ten private Catholic schools. The research results were congruent with global educational policy implementation research and suggested future lines of inquiry specific to Lebanon.
\end{abstract}

Index Terms - community service, Catholic education, educational policy implementation, policy-making, citizenship

\section{INTRODUCTION}

Education in conflict areas is sometimes perceived as being part of the problem rather than the solution (Bush \& Saltelli, 2000). More specifically, education was found to play a role in both the development and exacerbation of conflict. On the one hand, evidence suggests that education is a human right that contributes to the promotion of social cooperation and understanding and builds an internal collective solidarity (Pherali, 2019). The UNESCO Commission for Education highlights the positive and civilizing power of education, revealing that it is a means to reduce poverty, crime, exclusion and ignorance, creating greater harmony in a community and fostering social peace (1997, p.11). On the other hand, education can also have a destructive impact (Bush \& Saltarelli, 2000) and as per Sommer (2002), "many who conduct modern wars are expert at using educational settings to indoctrinate and control children" (p.8). Educational institutions sites of influence that help form the personality and outlook of their students and are sometimes abused for the purpose of establishing war propaganda. It is thus suggested that the purpose of educational institutions changes depending on the context and situation of the country in question, whether it is at peace or at war.

The educational system has been advocating community service in the youth for social cohesion purposes and an overall development of the overall community. Research suggests that active involvement in community service predicts later civic engagement (Hart et al., 2007). For instance, it was found to help shape the students' identity as many students do service at sites managed by non-governmental organizations (NGOs) as a response to social crises such as extreme poverty or homelessness. A study by Huda et al. (2018) disclosed that students' engagement in community service was positively associated with the development of greater civic responsibility. Acquired civic values in turn contribute to their personal as well as social development as they start to identify themselves as individuals who are capable of positive public involvement. Furthermore, community service was established to be valuable for students' self-exploration and the development of their leadership skills by providing them the chance to make meaningful changes and witnessing the consequences of their actions (Dewey, 1916). The latter highlights the significance of community service and how it can be beneficial on both a societal and personal level.

Social cohesion was found to cater for societal needs in times of conflict (Aall \& Crocker, 2019). It was stated by the UN Research Institute for Social Development that a government's role should be to create programs encouraging national cohesion in order to improve social welfare and promote integration in shaping attitudes towards peace (2003). As an example, a study conducted in Lebanon explored the impact of community kitchens and their establishment in Syrian refugee camps. Results revealed that this act of service enhanced nutrition education among women in the camps, reduced social isolation and improved cooking and food management skills in low-income families in a context of war and displacement (Ibrahim, Abou Haidar \& Jomaa, 2019). The latter displays how small initiatives can make a positive contribution to furthering the community's interests.

While the Lebanese Ministry of Education and Higher Education (MEHE) issued Decree No. 8924 "Project Community Service in Public and Private Secondary Schools", a gap in the literature still exists regarding its implementation in Lebanon. To our knowledge, no recent published study describes the experiences of schools when implementing the Decree and a study to tackle this would be the first of its kind in studying the impact of change on students, teachers and parents. Lebanon is a country that experienced a civil war for almost fifteen years. In addition to this, it is currently fac- 
ing a refugee crisis, with the influx of almost one million Syrian refugees in 2019. Opportunities for affordable education are limited, and poverty sometimes leads to negative coping mechanisms such as child labor or child marriage. Based on past literature, the establishment of community service in conflicted areas can have a positive and significant impact on the wellbeing of the general community. At present, debates on the implementation of the Decree are arising and school headmasters are determining the risks and benefits of such a decision. Research on this matter contributes to literature by evaluating the extent to which the implementation of community service across Lebanese high schools can successfully meet the Decree's aims of cultivating citizenship and social cohesion among students.

In Lebanon, the main policy-making actors are the Parliament and the Council of Ministers. The Council is responsible for setting the general policy of the state in all domains, approving draft bills and decrees, and overseeing the implementation of laws. In 2012, the Council approved the above-mentioned Decree Number 8924 (The decree states that all schools should apply a mandatory 60-hour community service program across the three secondary school years covered in the study (approximately 14 to 18 year-old students). From an educational perspective, global research examining the effectiveness of community service in schools and universities has been prolific. The general consensus is that it is an effective tool for the academic, personal, and social development of students. However, research examining the impact of community service on students remains scarce in Lebanon and the region. Moreover, there is a deficit in the MENA region in terms of studying the implementations of educational policies. This research seeks to fill in these gaps by examining the implementation Decree No. 8924 in light of existing research on policy implementation and the experience of ten private Catholic schools following the decree.

\section{CONCEPTUAL FRAMEWORK}

\section{A. Education Policy}

The implementation of education policy is a complex and evolving process that requires and involves input from several stakeholders. Measuring policy outcomes in education is particularly challenging, "because they take time to appear, and because it may be difficult to attribute learning performance outcomes to one specific policy" (Viennet \& Pont, 2017, p.11). Moreover, "few studies actually document reform impact or can specify what factors contribute to the policy's success" (Viennet \& Pont, 2017, p. 11). As a result, governments, experts, and international organizations have come to acknowledge the necessity of focusing on implementation processes (Gurría, 2015; Pont, 2008; Schleicher, 2016; Wagstaff, 2013).

Unlike the policy itself, the implementation strategy is action-oriented and must be flexible enough to cope with the unexpected (Fullan, 2015). When examining action strategies in Mexico, the OECD (2010) found that successful implementation was linked to the establishment of "a small number of clear, high-priority, measurable, ambitious but feasible goals focused on student outcomes, which do not distort practices within the school system (e.g. teaching to the test)" (OECD, 2010). Barber (2008) also stresses the importance of defining and prioritizing targets (i.e. objectives linked to figures) for effective policy implementation.

In fact, the design of an given policy is a main determinant in hindering or facilitating its implementation process, as the way in which a policy is formulated influences its enactment (Bell \& Stevenson, 2015). Haddad and Demsky (1995) argue that policy development should be based on evidence and a solid understanding of the education sector in general, as well as the socioeconomic, cultural, demographic, and political contexts. Moreover, the policy's underlying theory of change, or causal theory, is essential as it creates a narrative as to how and why the policy change will take place, and thus can guide and engage stakeholders (Fullan, 2015).

Another determinant of the policy's implementation is its context, i.e. the environment in which it is implemented, which can include institutional settings, existing policies and their complementarities, and events that can impact sociopolitical trends. According to Pont (2008), the speed and extent to which a policy is implemented is determined by constitutions, laws, rules, conventions, and norms or habits. Research also suggests that implementation is particularly affected by the compatibility of educational policies: only when policies are compatible and coherent is change possible in complex systems such as the education sector (Mason, 2016; Pont, 2017).

Research further suggests that policy actors, ${ }^{1}$ belief systems, interests, and motivations affect their perceptions and engagement with the policy (Malen, 2006; Spillane, Reiser \& Reimer, 2002). In this context, Malen defines interests as "the complex web of values, views, orientations, dispositions, preferences, and convictions that shape their perception of public problems and the policy solution that may be attached to them" (Malen, 2006, p. 87).

Pont highlights that when service providers, teachers, principals, and parents support a policy (rather than oppose it), its chances of effective implementation increase significantly (Pont, 2017). Moreover, the actors' capacities play a significant role in effective implementation. In a study conducted by Cheung and Man Wong, the teachers' professional development and the principals' leadership skills were found to positively affect policy implementation (Cheung \& Man Wong, 2012). Equally influential are the schools' organizational settings and their capacity: Bell and Stevenson (2015) argue that the manner in which organizations react to a given policy is shaped by organizational principles, structures,

1 The implementers of a policy may be identified as "stakeholders" or "actors", which can refer to both individuals and collective entities, whether formal or informal, across all levels of policy implementation. 
and internal procedures.

In light of these studies, this research seeks to examine Decree Number 8924, which holds that community service can positively impact students' development by fostering and strengthening essential democratic values such as citizenship, cooperation, social responsibility and accountability, as well as their personal and social identity.

\section{B. Community Service, Education, and Citizenship}

Existing research supports the claim that participation in service activities offers a wide range of benefits, both for the service provider, or volunteer, and for society at large. For instance, the experience of serving others appears to increase empathy, commitment to community, empowerment, and self-esteem (Raupp \& Cohen, 1992, p. 25). In an academic context, studies indicate that service activities open students to learning experiences that strengthen their interpersonal links with those they are serving, and that providing services enhances agency and social connections, moral-political awareness, as well as identity development (Yates \& Youniss, 1996, p. 85). In fact, participation in community service has been linked to the development of both personal and collective identity by encouraging students to develop a deeper understanding of themselves through meaningful work with others (Rhoads, 1997; Yates \& Youniss, 1997).

More recently, research indicates that community service positively impacts the acquisition of social skills, personal growth and satisfaction, professional improvement, and civic development and responsibility, where the welfare of others is enhanced by a collective effort (Watkins, Carnell, \& Lodge, 2007, p. 11). Furthermore, community service was proven to be a valuable opportunity for students' self-exploration and leadership development by providing a platform to take meaning from an experience by connecting the activity to its consequences (Dewey, 1916; Marks \& Jones, 2004; Rhoads, 1997). Research also shows that progress monitoring and evaluation to continually assess student learning and program goals are vital (Shumer \& Duckenfield, 2004, p. 141), and that community service is highly efficient in setting and meeting a clearly defined need when students participate in planning and carrying out the assigned project (Bosworth, Ford, Anderson, \& Paiz, 2016, p. 13).

Thus, evidence supports the belief behind Decree No. 8924, that community service can positively affect students' personal and social development. However, the success of the policy in meeting its goal of cultivating citizenship and strengthening civics education through community service alone is problematic, particularly in the Lebanese context.

Citizenship education is built around learning to live together and requires the availability of "opportunities that allow students to engage in dialogic and collaborative practices informed by understandings of rights and responsibilities" (Akar, 2016, p. 291). Moreover, young people develop their capacity for a life of peaceful coexistence by learning how to engage in constructive dialogue and to participate in social change (Bush \& Saltarelli, 2000, p. 54). Thus, schools can play a key role in enhancing students' social cohesion and active participation through community service, especially since good citizenship is represented through high levels of engagement in community-building activities (Akar, 2016).

However, research on civics education programs in Lebanon shows that the common practices of memorization and the adherence to prescriptive curricula were at odds with the very conceptualizations of citizenship (UNDP, 2008). Moreover, the various revisions of the Lebanese curriculum have focused on the learning and transmitting of information with little or no emphasis on "the development of analytical, evaluation, critical thinking and other necessary skills and competencies" (Frayha, 2003, p. 84). Plus, according to Hart et al. (2007), requiring community service of students either as a condition of high-school graduation or as part of a class results in a dull, possibly resented, activity that cannot deepen the students' commitment to the civic good (p. 200).

Therefore, this paper seeks to evaluate the extent to which the implementation of community service across Lebanese high schools can successfully meet the Decree's aims of cultivating citizenship and social cohesion among students.

\section{Methodology}

\section{A. Participants}

The principals of ten private Lebanese Catholic schools participated in this study. The schools are located in Mount Lebanon, target middle-income to high-income earners, adopt English and Arabic as languages of instruction, and host an average of 2,000 students each.

As mentioned previously, the socioeconomic and cultural context, as well as the institutional setting, play a major role in determining an educational policy's implementation process. As such, having a homogenous sample allowed for more consistent results and limited interference from external variables.

It should be noted that the study originally sought to include students through surveys and focus groups. However, the ten schools refused to grant permission to interview the students, which made it impossible to examine the students' perception of community service and its impact.

\section{B. Instruments}

Qualitative methods were used to gather and analyze the data in this study (Cohen, Manion, \& Morrison, 2000, p. 44). The interviews with the headmasters were guided by a semi-structured questionnaire that included three Likert scale items. The questions were based on existing literature and focused on examining the implementation process adopted by the schools, the challenges it entailed, and the perceived impact of community service on students. 


\section{Procedure}

The researcher first reached out to high-schools she had collaborated with previously during her time as the principal of a Catholic school. Due to the political sensitivities of education research in Lebanon, many schools are cautious of being externally evaluated and are reluctant to answer questions about personal experiences; thus, it was important that other school principals, or the potential interviewee's colleagues, personally introduced the interviewees to the study.

Of the contacted schools, ten agreed to participate. The principals received a copy of the interview questions a week before the interview. Each principal was aware of the researcher's background, had a copy of the research rationale and focus of the study, and was given a signed assurance of confidentiality. The interviews were conducted in each principal's office and were recorded with their permission.

One of the ten principals preferred to answer the interview questions in written form due to time constraints. Although this poses a limitation to the study, the researcher agreed as the principal heads an international private school that has been implementing community service as part of its curriculum since 2010, i.e. before the Decree was issued. Moreover, only her answers to the Likert scale questions are considered here as the number of participants for a Likert scale question to be reliable and valid (effective at 10:1), i.e. 10 participants for each item (Schreiber, Nora, Stage, Barlow, \& King, 2006).

\section{RESULTS}

In terms of the general feedback about the Decree's implementation, three of the ten principals indicated that their experience was very difficult, six found it complicated and challenging, and only one claimed it was easy because the school already considered 60 hours of community service to be a graduation requirement.

More specifically, the schools faced numerous administrative challenges and were incapable of complying with the Decree's guidelines. For instance, nine schools faced strong opposition from teachers. Instructors were reluctant to allocate time to community service hours at the expense of completing course content and refused to invest their time and effort in "trivial social work" that was a "complete waste of time", according to one headmaster.

Nine principals also faced administrative opposition to integrating the 60 service hours into the curriculum. The administrators argued that they had a program to accomplish in order to prepare their students for the Official Baccalaureate II exams. In an attempt to overcome these challenges, three schools suggested conducting community service hours during vacations and weekends, which was demotivating for both students and teachers. Consequently, the 60 hours of community service stipulated by the Decree were not fully implemented and the students' reports were not completed.

Six principals insisted that community service should be legally integrated into the curriculum and not taught as a separate entity. In their view, it should be conducted as an interdisciplinary project involving all teachers and across all subjects. One principal noted that community service must be mandatory. He claimed that there is a need to shift paradigms and to integrate the concept of community service into Lebanese culture stating that "when people become accustomed to the concept of community service, it can be turned into an optional activity in schools".

Eight principals perceived the absence of specialized community service units in their schools as a major obstacle for implementation. As such, the administrative follow-up with students and with external institutions had to be conducted by the schools' social service staff due to budget restrictions.

Nine principals attested that one of the most prominent challenges was the mentality and culture of what one called "traditional Lebanese society". According to them, community service is not well regarded by mid- and high-income Lebanese families, as if a child works while a student it is considered demeaning and humiliating to the parents.

Three principals were faced with issues of social class conflict. The school's wealthy families did not want their children to "mingle with and serve poor people", or to collect garbage, for instance. They wanted their children to "assist dentists and work as interns in banks" rather than attend institutions involved with social affairs.

Six principals experienced resistance from middle-income families pertaining to the importance of community service in their children's lives. The parents believed that their studies were of primary importance and that community service hours were a waste of time.

In terms of the community service activities that the schools were capable of implementing and completing, they primarily targeted neighboring communities in need, including refugees, children, and the elderly. While one school visited a Palestinian refugee camp where students helped paint houses, another organized for its students to provide after-school English lessons to young Syrian refugees. Through other projects, students helped disabled children supported by Anta Akhi, an association that tends to children with disabilities in Lebanon and supports their families, with their homework. Some schools coordinated with Caritas Lebanon to allow for students to help during their food drive by delivering donations to shelters. One school in particular focused on ecological issues pertaining to garbage recycling. Students visited all the houses in the school's neighborhood and explained the importance of recycling, as well as the process of separating garbage and using the proper bins. As for the elderly, one school's students raised funds and invited 20 seniors to a lunch they prepared followed by entertainment activities they had organized beforehand.

As for the impact of community service on students, all ten principals reported difficulty in quantifying these effects. They admittedly formulated their views based on their personal observations and the reports they received from students.

Eight principals attested that they witnessed an increase in social commitment among the students. Four reported that 
some students even went to volunteer outside their local area during the summer.

All ten principals stated that empathy was very hard to measure and observe. They rated empathy development through the students' willingness and readiness to participate in community service along with their efforts in understanding and caring for others as reflected in their reports and oral presentations.

Nine principals reported that a significant increase in their student's appreciation of diversity was noted through the students' attitudes and written reports. For instance, the principals cited statements such as "a Syrian refugee can be my friend because he can teach me new things", and "a Muslim student in my class is very helpful and taught me how to work better in a group to better support the others".

Seven of the ten principals attested that a significant increase in the students' sense of responsibility was tangible through their reports and attitudes towards interdisciplinary projects related to community service.

When asked about the link between community service and civic education, active citizenship, and social engagement, the nine interviewed principals recommended that students conduct service hours in their own communities. They claimed that such direct involvement would increase coherence and cohesion within the community, and through service, all parties would be working hand in hand to enhance the quality of life of the less fortunate and needy.

\section{DISCUSSION}

This research examines the implementation of Decree 8924 in ten private Lebanese Catholic schools. With the exception of one school, which already required community service as a graduation requirement for the International Baccalaureate, all the interviewed principals reported that policy implementation was difficult, if not impossible, due to numerous challenges.

Within the schools, principals faced strong opposition from both the teachers and the administration. The study's results are congruent with existing literature on stakeholder impact on policy implementation (Pont, 2017; Bell \& Stevenson, 2015). Moreover, research suggests that stakeholders' belief systems, motivations, and interests (values, views, orientations, dispositions, etc.) shape their perception of public policy and determine their engagement (Malen, 2006; Spillane, Reiser \& Reimer, 2002), which was observed through the reactions of teachers and parents alike. Furthermore, all the principals highlighted their lack of organizational readiness to successfully implement the policy, whether in terms of budget or specialized units; a result that is in line will Bell and Stevenson's research.

However, an interesting finding of this research was the unanimity of the opposition from the schools' administration, the teachers, and the parents. All three groups appear to agree that academic learning is more important than community service. For instance, instructors refused to "waste time" at the expense of course programs, and some parents preferred their children to study rather than serve others. This collective valuing of academic learning over social service suggests a cultural determinant of the policy's implementation. Moreover, unlike previous studies that highlight the role of a policy's complementarities, and their compatibility with other laws, rules, conventions, and norms (Desimone, 2002; Mason, 2016; Pont, 2008; Pont, 2017), this study suggests a hierarchy of values: in this case, the value of academic learning supersedes that of community service.

Identifying the reasons behind this apparent hierarchy is beyond the scope of this research. However, several interpretations can be hypothesized. First, academic achievement is generally highly valued in Lebanese society. One possible reason for that is the cultural correlation between academic success and career development. Second, it was clear from the interviews that community service was perceived as mere volunteer work that bordered on charity. The prioritizing of self-development over social development can be related to the broader individualistic culture and the residue of the Civil War mentality of "every man for himself". Additionally, the following should be noted: it was interesting that, even when understood as a form of charity, community service gave way to academic learning, especially in the context of the Catholic schools in this study. As such, the effect of religious affiliation on how community service and academic learning are perceived requires further research.

The (mis-)understanding of the nature of community service can also be linked to the ambiguity of the policy's language and rationale. On the one hand, the Decree did not connect its objective (to enhance social cohesion and civic engagement) to its tool (community service). In other words, there was no underlying theory of change (Fullan, 2015), as the Decree failed to explain how and why community service would result in change. In addition, legislators failed to connect community service to the educational setting. The Decree stipulated the implementation of community service during course hours, and in compliance with the curriculum; it did not advocate a service-learning model but sought the mere complementarity between the type of service performed and the curriculum's objectives (more specifically, the objectives of particular subjects such as languages, social studies, civics, and arts). The lack of a clearly defined servicelearning model could explain why teachers and principals recommended the integration of community service into the curriculum.

In terms of the impact following the integration of community service into schools, principals claimed an increase in social commitment and empathy, as well as an enhanced sense of responsibility and respect for diversity among students. However, the researcher was denied access to interview students about their community service experience. This denial could imply a certain lack of transparency on the part of the schools and raises questions as to the democratic values they are fostering (interfering with the students' freedom of expression for instance by not allowing them to participate in the study). More importantly, self-reflection, critical evaluation, and participation in dialogue (Akar, 2016; 
Bush \& Saltarelli, 2000; Frayha, 2003; Hart et al., 2007) have all been identified as essential components of community service and citizenship education. The schools' refusal to allow the researcher to interview students could be interpreted as a failure to provide them with the chance to fully benefit from their community service experience and to grow as citizens.

Nonetheless, taking the principals' feedback at face value, there were two specific elements of diversity that the students reported: some of the students appear to have gained a certain appreciation and respect for religious and national diversity. The extent to which this valuing of diversity is impactful and sustainable requires further examination. There seems to be some foundation for the Decree's logic of implementing community service in order to foster respect for diversity. However, it is far from clear that community service can counter the culture of corruption, inequality, and sectarian divisions that the Decree sought to address. In fact, this very same culture seemed to hinder its effective implementation. For instance, parents protested their children's participation in numerous service activities because they are perceived as degrading and "beneath" their social status. Instead, they preferred their children to assist dentists or bankers. While this preference might stem from the parents' desire for their children to acquire direct professional experience, it can also be related to social class issues and conflicts.

Finally, the research revealed the existence of a powerful stakeholder in education policy implementation, namely parents. While previous research acknowledged the role parents play in supporting or objecting to policies, this study showed their influence on school administrations and the pressure they were capable of exerting. While this observation could be related to the cultural context (it is not uncommon for Lebanese parents to be directly involved in all aspects of their children's lives), it requires and deserves further examination.

\section{Limitations OF THE STUdy AND SUGGESTIONS FOR FutURE RESEARCH}

This study sought to examine the implementation of Decree 8924 in Lebanese high-schools. The research consisted of interviews with the principals of ten private Catholic schools, a factor which could affect the representativeness, validity, and reliability of the results on a national scale. Additional quantitative research could involve a wider and more inclusive sample to support the results and to better understand the impact of community service on students and the educational community as a whole in Lebanon.

Although the ten schools were from different regions, i.e. from urban and rural areas within Mount Lebanon, they were all private schools with students of a relatively high socio-economical status. Future studies need to include a more varied sample, including students from different socio-economic backgrounds as well as public and private schools throughout the country. Moreover, further research should compare schools with different religious affiliations.

This research was a case study, which is a natural limitation when exploring educational and teaching experiences (Cohen, Manion, \& Morrison, 2000, p. 167). The principals appeared transparent and honest when noting many of the challenges faced while attempting to apply the Decree; however, they might have chosen to report on the positive experiences taking place at their schools rather than reporting on any extremely negative instances.

Additionally, the refusal to allow the researcher to interview students raises questions as to the interviewed principals' transparency. Although schools must safeguard students' privacy, the impact of community service cannot be fully studied without their participation.

A future study could further determine the accuracy of the data through triangulation, by comparing the attitudes of principals, teachers, and students.

Finally, although the principals reflected on specific incidents that took place while applying the Decree in their schools, future on-site observation could validate and expand the data gathered in this study.

\section{CONCLUSION}

There have been scattered efforts to follow how Decree 8924 is being implemented across Lebanon, with no exhaustive and thorough study yet documented. This research seeks to fill this gap by examining the implementation of community service across ten private Catholic schools. The researcher sought to explore if these schools were capable of implementing the Decree and the different types of challenges they faced during implementation. In parallel, the author was interested in evaluating the Decree's success in reaching its objectives, especially in terms of cultivating citizenship. The research results were congruent with global educational policy implementation research and have resulted in suggestions for future lines of inquiry specific to Lebanon.

\section{APPENDIX. EXCERPT FROM CERD's (CENTER FOR EDUCATIONAL RESEARCH AND DEVELOPMENT) DECISION UNDER} DECREE NO. 8924

Article Number 1:

The project of "community service" is applied in all private and public high-schools starting the academic year $2012-2013$

Article Number 2: 
The "community service" periods in the secondary cycle are set for 60 hours of effective service applied during the 3 years of secondary education. It is possible to apply those periods during 2 years instead of 3 , on the condition that the periods of effective execution do not exceed 40 hours in one year.

Article Number 5:

Scheduling of the execution periods of "community service" occurs as follows:

-Planning, preparation, and discussion periods are held during regular school opening hours

-Periods of actual execution of the project occur outside school working hours

-Periods of assessment of general and specific concepts and principles acquisition as well as good execution and skills acquisition are conducted during regular school opening hours

Planning, preparation, discussion, and assessment periods are allocated 10 to $15 \%$ from the total periods allocated to the project.

Article Number 6:

The execution of "community service" projects starts at the beginning of the academic year and ends during the last week of June for First and Second Secondary classes, and at the end of May for Third Secondary classes.

Article Number 7:

The theme choice and execution periods of the "community service" projects happens in concordance with the different goals of the subject matters and their related content. Furthermore, students' preferences and their interests, capabilities, and execution possibilities should be kept in mind. The choice and execution of the projects should be based on the diversity of fields listed in Decree number 8924, dated 21/9/2012, to offer diversified opportunities that will meet the needs of the individuals and society as a whole.

Article Number 8:

A team should be formed in each high-school, headed by the principal, or a person that represents him/her, to study the concerned students' suggested projects, to choose the most appropriate ones, and to define the execution mechanisms as well as the relative follow up inside and outside the high-school. The team should encompass between 3 and 5 teachers depending on the number of categories and the diversity of the projects.

Article Number 9:

The choice of the above mentioned team members in Article 8 should be based on:

-Teaching experience not less than 3 years in the secondary cycle

-Having a wide general knowledge background, an open mind and communication skills; along with commitment to their job and readiness to bear responsibility and follow it up.

-Good command of the Arabic language and either/or French or English

-Readiness to actively participate in activities inside and outside the school

-Realization of the importance of community service and its impact on student/citizen upbringing

Article Number 10:

Choosing the teachers who will be on the team is done based on the subject matters they teach and that represent the objectives and contents of "social service". Those subjects are: languages, social studies, physical education, arts and diverse activities.

Article number 11:

The tasks and responsibilities of the team are defined as follows:

-Taking part in the choosing the projects based on the students' suggestions, interests, and preferences.

-Contributing in discussing the chosen projects and providing any necessary clarifications.

-Keeping record of models and lists relative to the chosen projects' titles and the participating students.

-Making the necessary contacts with the centers or organizations where the projects will be executed.

-Participating in providing adequate explanations for good execution as well as facilitating students' tasks to obtain relative information.

-Following up on projects and keeping up with their progression to provide opportunities for success.

-Partaking in the process of evaluation that occurs after finishing the projects.

Article Number 12:

The cost of the execution and requirements of the community service projects is covered, when needed, from the quarterly activities students perform, from donations that are allocated for these projects and other similar projects, and from the high-school fund that covers the extra-curricular activities' expenses .

Article Number 13:

The working hours of the "team" is set as part of the decreased periods (deducted from the total of the working hours assigned by the law at the secondary level) allowed for teachers as stipulated in Law number 156 dated $17 / 8 / 2011$ and as part of the extra-curricular activities that are effected during the gradual decreased periods as per the provisions stated in Decree number 5334 dated 5/11/2010.

Article Number 14:

The team evaluates the projects' execution in order to check the students' acquired skills, their performance, and their successful execution of the project along with the extent of their evolution in different societal situations.

Article Number 15: 
The principal of the high-school should submit to the Directorate General for Education by the end of June of each year at the latest, a list with the students' names who completed the "social service" projects with the relative projects' titles along with the organizations that cooperated in the execution process. This list should rely on official attestations signed by the people in charge in those organizations or instances. Obtaining the graduation certificate of the general high-school degree, in all fields, is associated with the student's completion of the effective social service periods outlined by this decree.

\section{REFERENCES}

[1] Akar, B. (2012). The space between civic education and active citizenship in Lebanon. In Shuayb, M. (Ed.), Rethinking Education for Social Cohesion. Palgrave Macmillan, London, 154-170.

[2] Akar, B. (2016). Learning active citizenship: conflicts between students' conceptualisations of citizenship and classroom learning experiences in Lebanon. British Journal of Sociology of Education, 37(2), 288-312.

[3] Al-Nakib, R. (2012). Human rights, education for democratic citizenship and international organizations: findings from a Kuwaiti UNESCO ASPnet School. Cambridge Journal of Education, 42 (1), 97-112.

[4] Barber, M. (2008). Instruction to deliver: Fighting to transform Britain's public services. Methuen Publishing, London.

[5] Bell, L., \& Stevenson, H. (2015). Towards an analysis of the policies that shape public education: Setting the context for school leadership. Management in Education, 29(4), 146-150. http://dx.doi.org/10.1177/0892020614555593 (accessed 08/07/18).

[6] Bosworth, K., Ford, L., Anderson, K., \& Paiz, D. (2006). Community Service as an Alternative to Suspension Smith Prevention Initiatives. http://www.serviceoptions.org/documents/manual.pdf (accessed 08/07/18).

[7] Bringle, R. G., \& Hatcher, J. A. (1995). A Service-Learning Curriculum for Faculty. Michigan Journal of Community ServiceLearning, 2, 112-122.

[8] Bteddini, D., Barazi, R., Afifi, R., \& Nakkash, R. (2014). We don't want you to walk the streets we walked. International Journal of Adolescence and Youth. 19 (2), 232-244.

[9] Bush, K. D., \& Saltarelli, D. (2000). The two faces of education in ethnic conflict: Towards a peacebuilding education for children.Florence: UNICEF, Innocenti Research Center.

[10] Cerna, L. (2014). Trust: what it is and why it matters for governance and education. OECD Education Working Papers, No. 108, OECD Publishing, Paris, http://dx.doi.org/10.1787/5jxswcg0t6wl-en (accessed 08/07/18).

[11] Chapman, B. (2002). A bad idea whose time is past: The case against universal service. Brookings Review, 20(4), 10-14.

[12] Cheung, A. C., \& Man Wong, P. (2012). Factors affecting the implementation of curriculum reform in Hong Kong: Key findings from a large-scale survey study. International Journal of Educational Management, 26(1), 39-54.

[13] Cohen, L., Manion, L., \& Morrison, K. (2000). Research methods in education. London: Routledge Falmer.

[14] Desimone, L. (2002). How can comprehensive school reform models be successfully implemented? Review of educational research, 72(3), 433-479.

[15] Dewey, J. (1897). My pedagogic creed. New York: E. L. Kellogg.

[16] Dewey, J. (1916). Democracy and education: An introduction to the philosophy of education. New York: Macmillan.

[17] Frayha, N. (2003). Education and social cohesion in Lebanon. Prospects, 33 (1), 77-88.

[18] Fullan, M. (2015). The NEW meaning of educational change, New York: Teachers College Press.

[19] Furco, A. (1996). Service-learning: A balanced approach to experiential education. Expanding Boundaries: Service and Learning. Washington DC: Corporation for National Service, 2-6.

[20] Gurría, A. (2015). 21 for 21: A Proposal for Consolidation and Further Transformation of the OECD. Paris: OECD. Peжим доступа: http:/www. oecd. org/about/secretary-general/21-for-21-A-Proposal-for-Consolidation-and-Further-Transformationof-the-OECD. pdf, дата обращения, 8, 2015.(accessed 10/07/18).

[21] Hart, D., Donnelly, T., Youniss, J., \& Atkins, R. (2007). High school community service as a predictor of adult voting and volunteering. American Educational Research Journal, 44 (1): 197-219.

[22] Haddad, W. \& T. Demsky. (1995). Education policy-making process: An applied framework, Paris: UNESCO.

[23] Honig, M. (2006). Complexity and Policy Implementation Challenges and Opportunities for the Field, in Honig, M. (ed.), New directions in education policy implementation, Albany, NY: State University of New York Press.

[24] Honnet, E. P., \& Poulson, S. J. (1989). Principles of good practice for combining service and learning. Wingspread Special Report. Racine, WI: The Johnson Foundation, 1-15.

[25] Huberman, M., \& Miles, M. (2002). The qualitative researcher's companion. London: SAGE.

[26] Huda, M., Jasmi, K. A., Alas, Y., Qodriah, S. L., Dacholfany, M. I., \& Jamsari, E. A. (2018). Empowering Civic Responsibility: Insights From Service Learning. In S. Burton (Ed.), Engaged Scholarship and Civic Responsibility in Higher Education (pp. 144-165). Hershey, PA: IGI Global. doi:10.4018/978-1-5225-3649-9.ch007

[27] Ibrahim, N., Honein-AbouHaidar, G., \& Jomaa, L. (2019). Perceived impact of community kitchens on the food security of Syrian refugees and kitchen workers in Lebanon: Qualitative evidence in a displacement context. PloS one, 14(1), e0210814.

[28] Ingram, H., \& Schneider, A. (1990). Improving implementation through framing smarter statutes. Journal of Public Policy, 10(1), 67-88.

[29] Jansen, T., Chioncel, N., \& Dekkers, H. (2006). Social Cohesion and Integration: Learning Active Citizenship. British Journal of Sociology of Education. 27 (2): 189-205.

[30] Kielsmeier, J. (2011). Service-Learning: The Time Is Now. Prevention Researcher, 18 (1): 3-7.

[31] Malen, B. (2006). Revisiting policy implementation as a political phenomenon: The case of reconstitution policies, in Honig, M. (ed.), New directions in education policy implementation, Albany, NY: State University of New York Press. 83-104

[32] Marks, H. M., \& Jones, S. R. (2004). Community service in the transition: Shifts and continuities in participation from high school to college. The Journal of Higher Education, 75(3), 307-339. 
[33] Mason, M. (2016). Complexity theory and systemic change in education governance, in Burns, T. and F. Köster (eds.), Governing education in a complex world, OECD Publishing, Paris, https://www.oecd-ilibrary.org/education/governing-education-in-acomplex-world/complexity-theory-and-systemic-change-in-education-governance_9789264255364-4-en (accessed 08/07/18).

[34] Metz, E. \& Youniss, J. (2003). A demonstration that school-based required service does not deter but heightens volunteerism. Political Science and Politics, 36 (2): 281-286.

[35] Ministry of Education. (MEHE, 1997). The programmes of general education and their aims. Beirut: Ministry of Education.

[36] Nabti, P. M. (2006). Learning to care: Education, volunteering, and community service. Beirut: Association of Volunteer Services.

[37] OECD (2010). Improving schools: strategies for action in Mexico, Paris: OECD Publishing.

[38] Osler, A. (2010). Students' perspectives on schooling. Maidenhead: Open University Press.

[39] Palmon, S., Cathcart, A., Lembeck, P. T., \& Peterson, R. L. (2015). Service learning and community service. Strategy Brief. Lincoln, NE: Student Engagement Project, University of Nebraska-Lincoln and the Nebraska Department of Education. http://k12 engagement.unl.edu/service-learning (accessed 10/07/18).

[40] Perkins-Gough, D. (2009). Special report: Can service-learning keep students in school? Educational Leadership, 66 (8): $91-$ 93.

[41] Pherali, T. (2019). Education and conflict: Emergence, growth and diversification of the field. Education and Conflict Review, 2, 7-14.

[42] Phipps, A. (2013). Intercultural ethics: Questions of methods in language and intercultural communication. Language and Intercultural Communication, 13 (1): 10-26.

[43] Pont, B., Nusche, D., \& Moorman, H. (2008). Improving school leadership, Volume 1: Policy and practice. Australia: OECD Publications. https://www. oecd. org/edu/school/44374889.Pdf, (accessed 09/10/16).

[44] Pont, B. (2017). Education reforms: School leadership in comparative perspective. Madrid: Universidad Complutense.

[45] Qualifications and Curriculum Authority. (1998). Education for citizenship and the teaching of democracy in schools. Final Report of the Advisory Group on Citizenship (The Crick Report). London: QCA. P.57

[46] Raupp, C., \& Cohen, D. (1992). A thousand points of light, illuminate the psychology curriculum: Volunteering as a learning experience. Teaching of Psychology, 19 (1): 25-30.

[47] Rhoads, R. A. (1997). Community service and higher learning: Explorations of the caring self. Albany: State University of New York Press.

[48] Sabatier, P., \& Mazmanian, D. (1980). The implementation of public policy: A framework of analysis. Policy Studies Journal, 8(4), 538-560.

[49] Schreiber, J. B., Nora, A., Stage, F. K., Barlow, E. A., \& King, J. (2006). Reporting structural equation modeling and confirmatory factor analysis results: A review. The Journal of Educational Research, 99(6), 323-338.

[50] Schleicher, A. (2016). Teaching Excellence through Professional Learning and Policy Reform: Lessons from Around the World, International Summit on the Teaching Profession, OECD Publishing, Paris. http://dx.doi.org/10.1787/9789264252059-en (accessed 09/07/18).

[51] Shuayb, M. (2015). Human rights and peace education in the Lebanese civics textbooks. Research in Comparative and International Education, 10 (1): 135-150.

[52] Shumer, R. \& Duckenfield, M. (2004). Service-learning: Engaging students in community-based learning. In F. P. Schargel and J. Smink (eds), Helping students graduate: A strategic approach to dropout prevention. Larchmont, New York: Eye on Education, 155-163.

[53] Singha, K. (2013). Conflict, state and education in India: a study of Manipur. American Journal of Educational Research, 1(6), 181-193.

[54] Sommers, Marc (2002). Youth: Care and protection of children in emergencies: A field guide. Washington, DC: Children in Crisis Unit, Save the Children US.

[55] Spillane, J. P., Reiser, B. J., \& Reimer, T. (2002). Policy implementation and cognition: Reframing and refocusing implementation research. Review of Educational Research, 72 (3), 387-431.

[56] Starkey, H., Akar, B., Jerome, L., \& Osler, A. (2014). Power, pedagogy and participation: Ethics and pragmatics in research with young people. Research in Comparative and International Education, 9 (4): 426-440.

[57] UNDP, MEHE, and CDR. (2008). Education and citizenship: Concepts, attitudes, skills and actions: Analysis of survey results of $9^{\text {th }}$ grade students in Lebanon. Beirut: UNDP.

[58] UNESCO (1994). Integrierter rahmenaktionsplan zur friedens-, menschenrechts- und demokratie-erziehung, www.friedenspaedagogik.de/ frieden/globlern/gl_10.htm (accessed 18/07/18).

[59] UN-SDG. (2015). 17 sustainable development goals to transform our world. www.un.org/sustainabledevelopment/ (accessed $06 / 07 / 18)$.

[60] United Nations Research Institute for Social Development. (2003). Social cohesion and conflict. Research for Social Change (UNRISD Fortieth Anniversary $\quad$ Report), Chapter 3. http://www.unrisd.org/unrisd/website/document.nsf/(httpAuxPages)/2E3C00CD605CC744C1256E35004BBB9B?OpenDocum ent\&panel=additional (accessed 11/07/18).

[61] Viennet, R. \& B. Pont. (2017). Education policy implementation: A literature review and proposed framework, OECD Education Working Papers, No. 162, Paris: OECD Publishing, https://doi.org/10.1787/fc467a64-en (accessed 07/07/18).

[62] Wagstaff, A. (2013). Reconciling the two sciences of delivery, Let's Talk Development World Bank Blog, http://blogs.worldbank.org/developmenttalk/reconciling-the-two-sciences-of- delivery (accessed 07/07/18).

[63] Watkins, C., Carnell, E., \& Lodge, C. (2007). Effective learning in classrooms. London: Paul Chapman.

[64] White, S., \& Choudhury, S. (2007). The politics of child participation in international development: The dilemma of agency. The European Journal of Development Research, 19 (4): 529-550.

[65] Yates, M., \& Youniss, J. (1996). A developmental perspective on community service in adolescence. University of Nebraska Omaha, School K-12, Paper 38: 85-102. 
[66] Yates, M. \& Youniss, J. (1997). Community service and social responsibility in youth. Chicago: The University of Chicago Press.

Maha Mouchantaf is an assistant professor at Notre Dame University (NDU), Louaize, Lebanon, and the former chairperson of the Department of English, Translation, and Education. She holds a Ph.D. in Educational Management from Université de Corse France, an M.A. in Educational Management from the Lebanese American University, Lebanon, and a B.A. in Communication Arts, Journalism and Radio/T.V. Production from the same university.

Her main research has focused on exploring gender differences, cultural diversity, and leadership styles in administration. She has a rich experience in school management and her research interests continue to center on issues related to shaping better leaders as well as bridging the gaps in the Lebanese educational system, and service learning. She participated in the evaluation of the project "Relief and Reconciliation for Syria" carried out by FLPS/GIR and LERC from NDU.

She has conducted several trainings and workshops on Leadership and management and prevention of violent extremism with the British Council. She has published on female leadership in Lebanon and on issues pertaining to gender differences in school administration and service learning. 